Article

\title{
Dynamic Optimization of Boil-Off Gas Generation for Different Time Limits in Liquid Natural Gas Bunkering
}

\author{
Yude Shao ${ }^{\circledR}$, Yoonhyeok Lee and Hokeun Kang *(i) \\ Division of Marine System Engineering, Korea Maritime and Ocean University, 727 Taejong-ro, Yeongdo-Gu, \\ Busan 49112, Korea; shaoyude@kmou.ac.kr (Y.S.); yhocean@kmou.ac.kr (Y.L.) \\ * Correspondence: hkkang@kmou.ac.kr; Tel.: +82-51-410-4260; Fax: +82-404-3985
}

Received: 1 February 2019; Accepted: 19 March 2019; Published: 22 March 2019

check for updates

\begin{abstract}
This study focus on the optimal time limit of ship-to-ship (STS) liquid natural gas (LNG) bunkering by dynamic simulation. Based on this, a mathematical model for calculating the boil-off gas (BOG) amount was developed. With respect to the modeling of the study, the diameter of the bunkering line is set as 8 inch while that of the BOG return pipeline is set as 4 inch to satisfy the pressure of the receiving ship and BOG generation. The capacities of the cargo tank and fuel tank for bunkering and receiving ships are set as $4538 \mathrm{~m}^{3}$ and $700 \mathrm{~m}^{3}$, respectively. The results indicated that the BOG amount with different LNG bunkering time limit is variable. The BOG flow rate varies inversely with respect to the bunkering time limit after $20 \mathrm{~min}$. Additionally, it is necessary to control the bunkering time within 120 min since additional BOG is generated when the capacity of the pump exceeds $100,000 \mathrm{~kg} / \mathrm{h}$, and thus the tank pressure difference between bunkering and receiving ship may be reduced. It is believed that the results of the research could provide feasible assistance for STS LNG bunkering for the ports, and could give a specific guideline for the amount of the BOG generation.
\end{abstract}

Keywords: liquefied natural gas; gas fueled ship; ship-to-ship bunkering; boil-off gas; bunkering time limit; dynamic simulation

\section{Introduction}

The schedule for the application of the stringent sulfur limits issued by International Maritime Organization (IMO) from 2015 in the emission control areas (ECAs) is in effect. The sulfur fuel emission limit which controlled by less than $0.5 \%$ will covered all over the world till 2020, as shown in Figure 1 . Therefore, the current goal involves challenging ship owners and operators to determine feasible bunker for their fleet [1,2]. Three potentially feasible options include: (1) Choosing a more expensive high quality low sulfur fuel oil, such as marine gas oil (MGO), as opposed to heavy fuel oil (HFO); (2) Cleaning the exhaust gas to an acceptable emission level such as using an exhaust gas scrubber system [3]; (3) Using the liquefied natural gas (LNG) as a fuel for ships is a realistic and feasible solution while the previous studies had indicated $[4,5]$. 


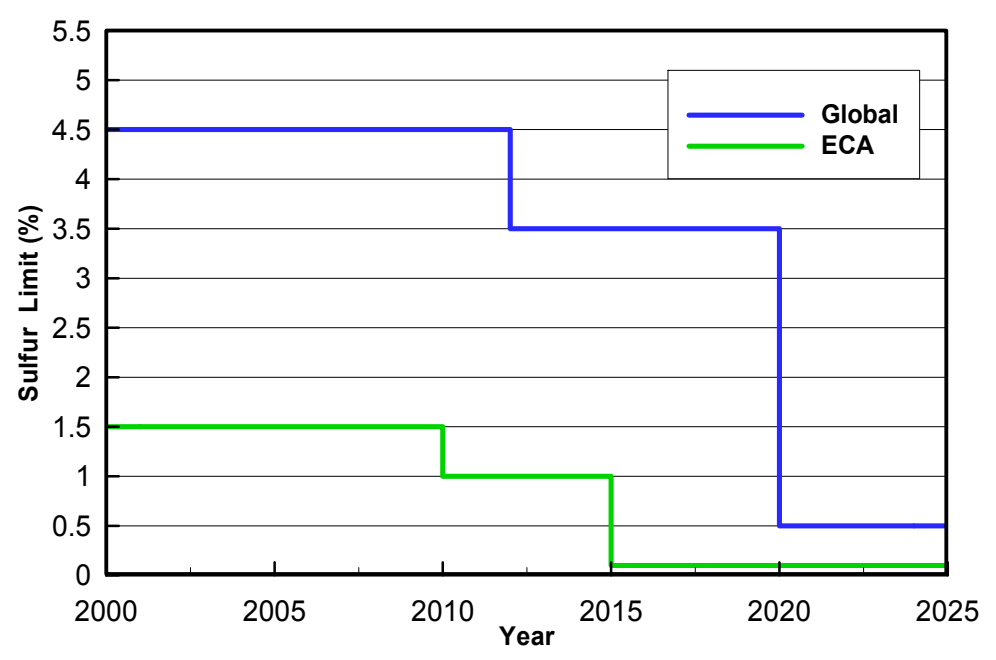

Figure 1. MARPOL Annex VI requirements of sulfur limits $\left(\mathrm{SO}_{\mathrm{x}}\right)$ [6].

Natural gas is mostly composed of methane $\left(\mathrm{CH}_{4}\right)$ which is a poisonless and flammable gas. Specifically, LNG is formed by refrigerating natural gas to a temperature below its boiling point (approximately $-162{ }^{\circ} \mathrm{C}$ ). The volume of the gas reduces by a factor of 600 after the liquefaction process, and thus it is widely available for transport and storage [7]. LNG is a cryogenic liquid and its transfer can generate a significant amount of boil-off gas (BOG), and thus the LNG bunkering procedure for LNG fueled ships differs from HFO bunkering [8]. The BOG generation could cause the overpressure of the LNG tank during LNG bunkering operation. The proper treatment methods for BOG include: (a) re-liquefaction at the bunkering ship, (b) use as a fuel, and (c) burn in the flare stack $[9,10]$.

For ships that use LNG as a fuel, LNG bunkering is an unavoidable process. The most effective method for LNG bunkering involves transferring LNG from bunker ships to a receiving ship (LNG fueled ship) in a manner similar to the loading of LNG cargo. LNG bunkering requires paying close attention to safe operations as it entails potential risks that are directly related to cryogenic liquid transfer and BOG returns, which significantly exceeds that of the HFO bunkering. Therefore, extant studies have focused on the bunkering procedure or safety of using LNG as a marine fuel [11-13]. Especially, Yun et al. [10] examined a conceptual design of an offshore liquefied natural gas (LNG) bunkering terminal for Busan port in Korea. As a case study, they performed a conceptual design by analyzing the statistics of visiting ships, estimating the required LNG consumption, and determining the process specifications and equipment features. Sun et al. [14] conducted a numerical analysis of hazardous consequence during ship-to-ship LNG bunkering that could involve the LNG vapor dispersion and LNG pool fires. They used computational fluid dynamics (CFD) models to qualitatively and quantitatively examine the main characteristics of different hazard types, vapor dispersion, and fire radiation. Jeong et al. [15] using integrated quantitative risk assessment (IQRA), proposed a statistical method to determine the safe exclusion zone around the LNG bunkering station and identify the potential risks during LNG bunkering.

Also, various studies have been done on the behavior of the BOG generation at the LNG exporting terminals, the LNG-FPSO and during transportation by utilizing Aspen simulation software. Kurle et al. [16] proposed several BOG recovery strategies and using steady-state simulations for BOG generation at LNG exporting terminals using. In 2016, Kurle et al. [17] also conducted effects of the temperature of LNG ship-tank, the jetty boil-off gas (JBOG) compressor capacity and the rate of tank cooling on JBOG. Hasan et al. [18] worked on the minimizing boil-off during LNG transportation using the Soave-Redlich-Kwong (SRK) state property equation method to conduct dynamic simulations of LNG transportation processes. Yan and Gu [19] developed a full scale model to analyze the effect of the BOG generation, the mass flow rate and the pump head of the LNG offloading system during 
LNG transfer process from the floating production storage and offloading unit for liquefied natural gas (LNG-FPSO) to the LNG carrier.

Most of the earlier studies only focus on the large-scale LNG operations, and had overlooked the small-scale LNG fueled ships, especially the STS LNG bunkering with a pressure-vessel type tank [20]. The originality of this study is to use the dynamic simulation for finding the optimum STS LNG bunkering time limit, and focusing on the minimization of BOG generation. In the present study, the commercial software Aspen HYSYS [21] is used to investigate and analyze the change in BOG generation from the LNG fuel tank of the receiving ship for different LNG bunkering time limits. Furthermore, the current study addresses attempt to identify an optimization ship-to-ship LNG bunkering time limit based on the dynamic simulation. On this basic, a mathematical model for calculating the total amount of BOG generation has developed. Finally, this study would contribute to proper handling of BOG generation problems, and thus providing a reference guideline during STS LNG bunkering procedure.

\section{System Model and Procedure Design}

\subsection{Tank Geometry}

The size and capacity of bunker ships strongly depend on travel distances, requirements for multi-cargo capability, expected trade volumes, and characteristics of the receiving terminals. Generally, the capacity of the LNG bunkering ships ranges from 1,000 to $10,000 \mathrm{~m}^{3}$. As shown in Table 1, the IMO Type C pressure tank is installed on both of the ships, LNG tank volume of the bunkering ship is $4538 \mathrm{~m}^{3}$, diameter is $12.0 \mathrm{~m}$, and the length is $40.12 \mathrm{~m}$ based on expert consultations. Hence, for the receiving ship with an LNG tank volume of $700 \mathrm{~m}^{3}$, the diameter is $8.0 \mathrm{~m}$ and the length is $13.93 \mathrm{~m}$.

Table 1. Geometry for the LNG tanks of bunkering and receiving ships.

\begin{tabular}{cccc}
\hline \multicolumn{2}{c}{ Parameter } & Value & Tank Type \\
\hline \multirow{3}{*}{ Bunkering Ship } & Tank volume $\left[\mathrm{m}^{3}\right]$ & 4538 & \\
& Diameter $[\mathrm{m}]$ & 12.0 & \\
& Length $[\mathrm{m}]$ & 40.12 & IMO \\
\cline { 1 - 2 } Receiving Ship & Tank volume $\left[\mathrm{m}^{3}\right]$ & 700 & \\
& Diameter $[\mathrm{m}]$ & 8.0 & \\
& Length $[\mathrm{m}]$ & 13.93 & \\
\hline
\end{tabular}

\subsection{Determination of LNG Flow Rate}

The longer LNG is bunkered prior to use, and an increase in the number of times that it is transferred from one storage vessel to another increases the BOG generation. Four typical cases are used to determine the BOG generation change for different LNG bunkering time limits. The bunkering time limit sets of the cases correspond to 60,90120 and $150 \mathrm{~min}$, respectively. In the procedure of bunkering, the LNG mass flow rate adjusts to $72,000 \mathrm{~kg} / \mathrm{h}$ when the level of the LNG tank of the receiving ship reaches $85 \%$. Additionally, the initial LNG mass flow rate is calculated as 280,000 , 180,000, 125,000 and 100,000 kg/h for each case shown in Table 2.

Table 2. LNG mass flow rates during different bunkering time limits.

\begin{tabular}{ccc}
\hline Bunkering Time Limit [min.] & Initial Mass Flow Rate [kg/h] & $\begin{array}{c}\text { Mass Flow Rate [kg/h] } \\
\text { (After Tank's Level of Receiving } \\
\text { Ship Over 85\%) }\end{array}$ \\
\hline 60 & 280,000 & 72,000 \\
90 & 180,000 & \\
120 & 125,000 & \\
150 & 100,000 & \\
\hline
\end{tabular}


Generally, the bunkering limit denotes the maximum allowable liquid volume to which the fuel tank may be loaded, and which is expressed as the percentage of the total fuel tank volume. The limit depends on the LNG densities at the bunkering and reference temperatures and is determined as follows:

$$
\mathrm{BL}=\mathrm{FL}\left(\frac{\rho_{\mathrm{R}}}{\rho_{\mathrm{B}}}\right)
$$

Here, BL denotes the bunkering limit, FL denotes the filling limit, and subscripts $\rho_{R}$ and $\rho_{B}$ denote the LNG density at reference temperature and the LNG density at bunkering temperature, respectively. The typical bunkering limits for the LNG fueled ships are expected to range from $85 \%$ to $95 \%$ based on the fuel tank type, pressure relief valve setting, and other ship specific considerations [22]. Therefore, in the study, the bunkering time limit for each case is set to the level reached by the LNG fuel tank of the receiving ship at $90 \%$.

\subsection{Pipeline System Design}

The bunkering pipeline system consists of LNG transfer pipes (bunker pipes) and vapor return pipes (BOG pipes) between the cargo tank of the bunkering ship and fuel tank of the receiving ship. The bunker pipes and BOG pipes are sized related to the design flow rates of the system. The design flow rate is related to the capacity, temperature and the pressure of LNG fuel tank, also other factors including the flow velocity limits, the BOG return capacity and bunkering time limit [7]. Additionally, the flowrate depends on the achievable bunkering rate from the bunkering ship. In this study the maximum LNG transfer mass flow rate is set as $280,000 \mathrm{~kg} / \mathrm{h}$, and the LNG velocity is assumed to $6 \mathrm{~m} / \mathrm{s}$, as the mass density of LNG bunker is assumed to be $450 \mathrm{~kg} / \mathrm{m}^{3}$ [23]. The diameters of the LNG bunker pipes are calculated as approximately $192 \mathrm{~mm}$. Therefore, the diameter of the bunkering pipeline is set to 8 inch $(200 \mathrm{~mm})$ while that of the BOG pipeline is set to 4 inch $(100 \mathrm{~mm})$ to satisfy the pressure and BOG generation in the fuel tank of the receiving ship.

Mass Flow Rate:

$$
\dot{m}=Q \times \rho
$$

Transfer rate:

$$
Q=\frac{\dot{m}}{\rho}=\frac{280,000}{450}=622 \mathrm{~m}^{3} / \mathrm{h} \text { at } V=6 \mathrm{~m} / \mathrm{s}
$$

Pipeline diameter:

$$
D=\sqrt{\frac{4 Q}{\pi V}}=\sqrt{\frac{4 \times 622}{\pi \times 6 \times 3600}}=0.1916 \mathrm{~m} \fallingdotseq 192 \mathrm{~mm}
$$

where $\dot{m}$ presents the mass flow rate; $Q$ is the volume flow rate; $\rho$ is the mass density of LNG bunker; $V$ is the velocity of LNG; $D$ is the diameter of pipeline.

The LNG bunkering can be operated only after the LNG fuel tank is inert, purged, and cooled down. With respect to the beginning of the simulation, the cool down process is only considered to accomplish using cold natural gas or LNG.

During transfer, the ship's fuel tanks typically contain an amount of LNG. In general, the volume remaining in the tank before bunkering is called heel, this small quantity is necessary to keep the tank cold prior to bunkering. The required tank heel in receiving ship is normally calculated by the fuel gas designers and the tank designers according to several variables (tank size, ship motions, shape, heat inflow from external sources, gas consumption of the engines, bunkering and schedule of the voyage. But as a general rule of thumb, a tank heel of $5 \%$ can be assumed for initial design considerations. However, the description of heel in the existing LNG bunkering guideline is adapted from the LNG Carrier loading process. Meanwhile, heel is only used as a propellant for the LNG fueled ship. Consequently, in the case in the present study, it is assumed that the tank heel for the LNG 
receiving ship is $20 \%$ based on consultations with experts. Tank pressure during bunkering could be maintained at an acceptable ranges by consuming LNG or by using the BOG control methods.

The bunkering procedure by ship-to-ship is divided into two parts, namely startup and shutdown of the system as shown in Table 3. With respect to startup of the system modeling, it is necessary for several conditions to fit in the initial bunkering startup wherein the pressure and quality should be in a stabilized state and also a closed LNG bunker line should be present. During the procedure, five steps are involved in the modeling startup.

Table 3. Modeling of the system startup and shutdown.

\begin{tabular}{|c|c|c|}
\hline \multirow[b]{2}{*}{$\begin{array}{c}\text { Modeling of } \\
\text { System Startup }\end{array}$} & $\begin{array}{l}\text { Conditions for the Initial } \\
\text { Bunkering Dtartup }\end{array}$ & $\begin{array}{l}\text { (1) Conditions (pressure/quality) in the receiver tank and } \\
\text { bunker tank should be in a stable state. } \\
\text { (2) BOG return line/LNG bunker line should be closed. }\end{array}$ \\
\hline & Procedure Change & $\begin{array}{l}\text { (1) Open BOG valve (bunker tank side and receiver tank side) } \\
\text { for } 10 \mathrm{~s} \text {. } \\
\text { (2) Start the heat ingress in the bunker and receiver tank. } \\
\text { (3) Open the LNG Bunkering valve (receiver tank side) for } 10 \mathrm{~s} \text {. } \\
\text { (4) Start the LNG bunkering pump ( } 8.9 \mathrm{~s} \text { after startup) and } \\
\text { operate the flow controller } 9 \mathrm{~s} \text { after the starting point. } \\
\text { (5) Open the LNG bunkering valve (bunker tank side) for } 10 \mathrm{~s} \text {. }\end{array}$ \\
\hline \multirow{2}{*}{$\begin{array}{l}\text { Modeling of } \\
\text { System } \\
\text { Shutdown }\end{array}$} & Procedure Change & $\begin{array}{l}\text { (1) When the level of LNG fuel tank for the receiving ship } \\
\text { reaches } 85 \% \text {, the mass flow rate ramps down to } 72,000 \mathrm{~kg} / \mathrm{h} \text {. } \\
\text { (2) When the level of the LNG fuel tank for the receiving ship } \\
\text { reaches } 89.99 \% \text {, controller cut-off occurs. } \\
\text { (3) When the level of LNG fuel tank for receiving ship tank } \\
\text { reaches } 90 \% \text {, the pump power cut-off occurs and all valves are } \\
\text { closed for } 20 \mathrm{~s} \text { to prevent the surge phenomena. }\end{array}$ \\
\hline & Simulation Control & $\begin{array}{l}\text { (1) The size of the time step (Adaptive time stepping) is adjusted } \\
\text { to } 100-1,000 \mathrm{~ms} \text {. } \\
\text { (2) Setting of the Simulation Stop: } \\
\text { Finish filling and close all valves and then stop the system } \\
\text { after } 30 \mathrm{~s} \text {. }\end{array}$ \\
\hline
\end{tabular}

In the shutdown system, mass flow rate ramped down to $72,000 \mathrm{~kg} / \mathrm{h}$ when the level of fuel tank for the receiving ship reached to $85 \%$, and subsequently controller and pump should be cut-off when the conditions are satisfied. It should be noted that the simulation control is also under the aforementioned procedure during the cut-off.

\section{Dynamic Simulation}

\subsection{Dynamic Simulation Method}

Aspen HYSYS was used for the dynamic simulation to calculate and analyze the change in the BOG generation of the LNG fuel tank of the receiving ship for different bunkering times. The purpose of the study involves determining the optimal ship-to-ship LNG bunkering time limit.

With respect to the process modeling and thermodynamic analysis, we applied the Peng-Robinson Equation of State that can predict the thermodynamic properties of various hydrocarbons including LNG in a relatively accurate manner as follows [24,25]:

$$
P=\frac{R T}{V m-b}-\frac{a \cdot \alpha}{V m(V m+b)+b(V m-b)}
$$

Here, the parameters $\alpha, a, b$, and $\omega$ are defined as follows:

$$
a=0.45724 \frac{R^{2} T_{c}^{2}}{P_{c}}
$$




$$
\begin{gathered}
b=0.07780 \frac{R T_{c}}{P_{c}} \\
\alpha=\left[1+\mathrm{k}\left(1-T_{r}^{0.5}\right)\right]^{2} \\
\mathrm{k}=0.37464+1.54226 \omega-0.26992 \omega^{2} \\
T_{r}=\frac{T}{T_{C}}
\end{gathered}
$$

where $P$ indicates the pressure; $T$ is the temperature; $R$ is the gas constant; $V_{m}$ is mole volume; $a, b$ are the equation of state parameters; $\alpha$ is the function for reduced temperature and the acentric factor; $\mathrm{k}$ is the function for the acentric factor; $\omega$ is the acentric factor; $T_{C}$ is the critical temperature; $P_{\mathrm{c}}$ is the critical pressure, and $T_{r}$ is the temperature at critical point.

Figure 2 and Table 4 show the schematic process flow diagram (PFD) of the ship-to-ship LNG bunkering scenario and the conditions for the LNG tanks of bunkering and receiving ships. The STS LNG bunkering model used for dynamic simulation was composed of two LNG storage tanks for bunker and receiving vessel, a submerge LNG pump, the LNG bunkering pipeline (include an LNG hose), the BOG pipeline (include a BOG return hose), the emergency shutdown (ESD) valves, and the emergency release couplings (ERC). As recommended in Section 2.1, the LNG storage tank's capacities were $4538 \mathrm{~m}^{3}$ and $700 \mathrm{~m}^{3}$ for the bunkering and receiving ships, respectively. The case with an LNG bunkering time limit of $60 \mathrm{~min}$ was selected as the standard simulation condition. The LNG tank level of the bunkering ship and receiving ship prior to commencing bunkering were filled to $90.0 \%$ and $20.0 \%$, respectively. The initial temperature difference $(\Delta \mathrm{t})$ between the bunkering ship and receiving ship was $12.5^{\circ} \mathrm{C}$, with the pressure difference $(\Delta \mathrm{p})$ was approximately 3.0 bar. As shown in Table 4 , when the bunkering procedure was completed, there were clear differences in the physical properties of both the bunkering and receiving ships. The level of the bunker tank decreased from $90 \%$ to $77.1 \%$, whereas the level of the receiving ship increased from $20.0 \%$ to $90.0 \%$. Meanwhile, the temperature and pressure differences between the two ships became closer. The temperature difference $(\Delta t)$ between the bunkering tank and receiving tank changed from $12.5^{\circ} \mathrm{C}$ to $0.8^{\circ} \mathrm{C}$, the pressure difference $(\Delta \mathrm{p})$ also decreased from 3.0 bar to 0.2 bar.

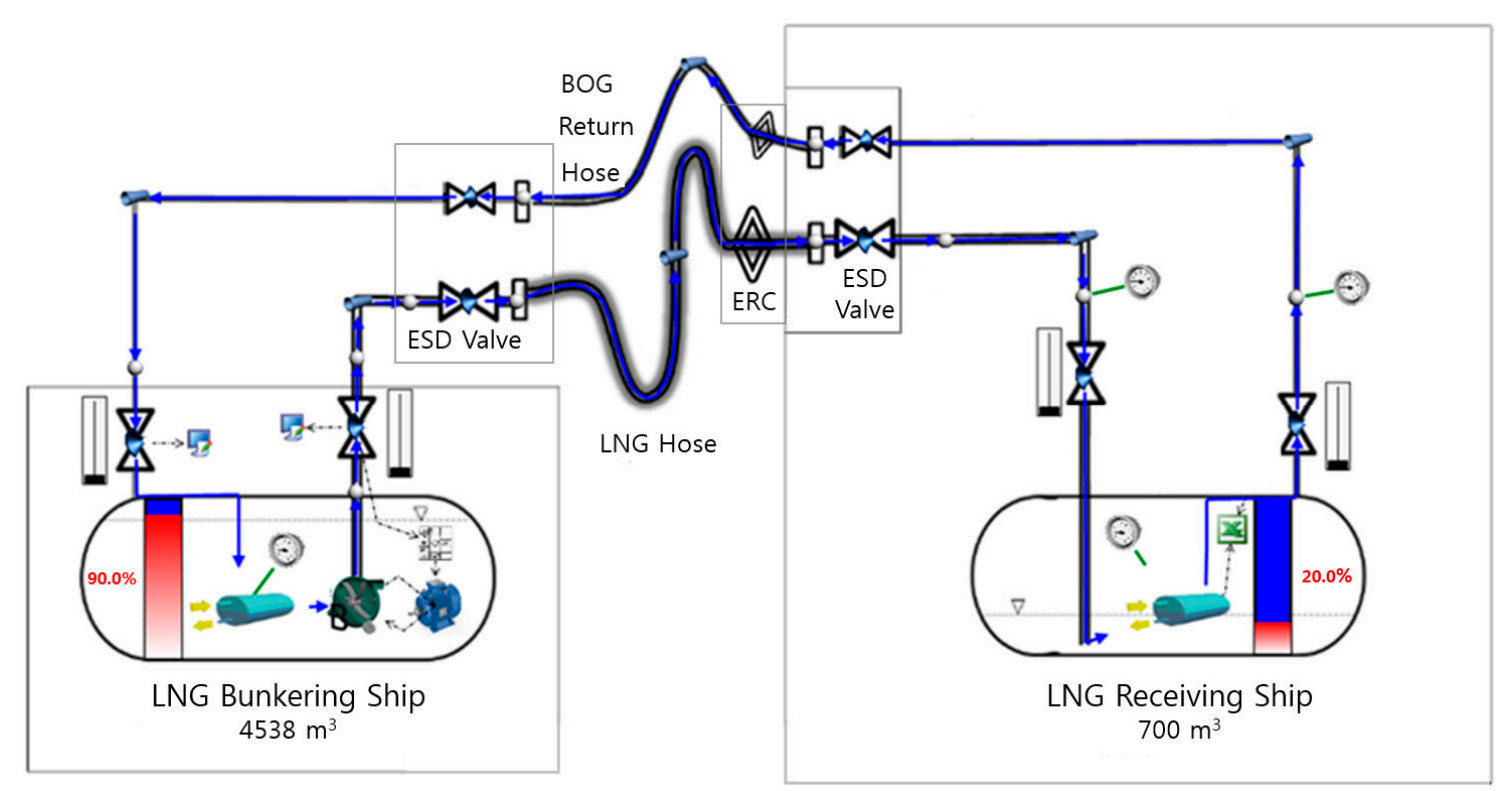

Figure 2. Simplified process flow diagram of the ship-to-ship LNG bunkering scenario (Begin Bunkering). 
Table 4. Conditions for the bunkering and receiving ships.

\begin{tabular}{|c|c|c|c|}
\hline & & Bunkering Ship (4538 $\left.\mathrm{m}^{3}\right)$ & Receiving Ship $\left(700 \mathrm{~m}^{3}\right)$ \\
\hline \multirow{3}{*}{ Begin Bunkering } & Tank level (\%) & 90.0 & 20.0 \\
\hline & Temperature $\left({ }^{\circ} \mathrm{C}\right)$ & -147.0 & -134.5 \\
\hline & Tank pressure (barg) & 2.8 & 5.8 \\
\hline \multirow{3}{*}{ Finish Bunkering } & Tank level (\%) & 77.1 & 90.0 \\
\hline & Temperature $\left({ }^{\circ} \mathrm{C}\right)$ & -146.4 & -145.6 \\
\hline & Tank pressure (barg) & 2.9 & 3.1 \\
\hline
\end{tabular}

\subsection{Code Validation}

As described in Section 1, the commercial software Aspen HYSYS is widely used for process dynamic simulation in the LNG industry, particularly in the field of BOG handling. It has been applied in many previous studies [18,26-29].

In this study, to verify the dynamic simulation model is conformed with the bunkering scenario, the amount of BOG generation was simulated, according to the initial temperature difference between bunker and receiving tank by applying HYSYS and Flownex. The temperature of the receiving tank was set at $-134.5^{\circ} \mathrm{C}$ as the standard initial temperature. Meanwhile, the temperature difference between bunker and receiving tank were $0.0,8.0,12.0^{\circ}$ and $16.0^{\circ} \mathrm{C}$, respectively. The Flownex is a commercial dynamic systems CFD code used as the primary thermal-fluid simulation code by the Pebble Bed Modular Reactor Company (PBMR). The comparison with experimental data excellently with the average differences of all cases was less than 10\% [30]. Both of the simulations were performed under the same condition. As shown in Figure 3, the total mass of BOG generation was quite similar to those of the Flownex simulation. The gap range for the results validated in each initial temperature difference was below $15 \%$. Especially when the initial temperature difference $(\Delta t)$ was $12.0{ }^{\circ} \mathrm{C}$, the gap range was below $2 \%$. Therefore, the HYSYS dynamic simulation could be used to conduct the dynamic behaviors of the STS LNG bunkering procedure.

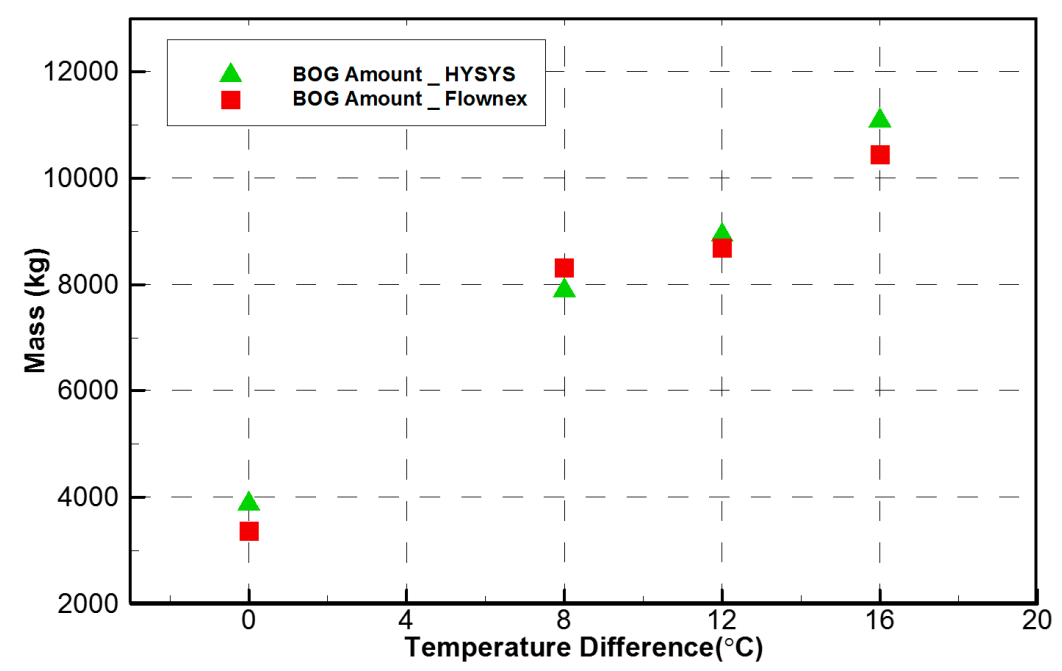

Figure 3. Comparison of HYSYS and Flownex simulation predicted the amount of BOG generation.

\section{Results and Discussion}

\subsection{Transient BOG Variation}

The property differences between the bunkered LNG and the LNG in the receiving ship can cause the problems that require carefully control of the BOG. In the most cases, the bunkering operation consists of filling a colder LNG (LNG bunkering ship) into a tank that contains a relatively warmer LNG (LNG fueled ship). 
The LNG density decreased when the temperature increased. If the receiving LNG tank was nearly full, the storage space for BOG was relatively low. Therefore, the increase in liquid volume due to lower density can significantly reduce the available volume of vapor space. The decrease in available BOG volume due to temperature changes increased the vapor pressure.

Figure 4 shows the BOG flow rate variation for different bunkering time limits. At the beginning of bunkering, a high amount of heat exchange was generated when LNG with low temperature was injected to the receiving ship, and thus the BOG flow rate peaked to $7 \mathrm{~kg} / \mathrm{s}$. In the initial $20 \mathrm{~min}$ for all the bunkering cases, the BOG flow rate was directly proportional to the bunkering time limit, i.e., an increase in the bunkering time limit increased the BOG flow rate that was generated. Conversely, the BOG flow rate was inversely proportional to the bunkering time limit after $20 \mathrm{~min}$. At the end of the bunkering scenario, the BOG flow rate corresponded to $1.24,0.55,0.322$, and $0.267 \mathrm{~kg} / \mathrm{s}$ for the time limits corresponding to $60,90,120$ and $150 \mathrm{~min}$, respectively.

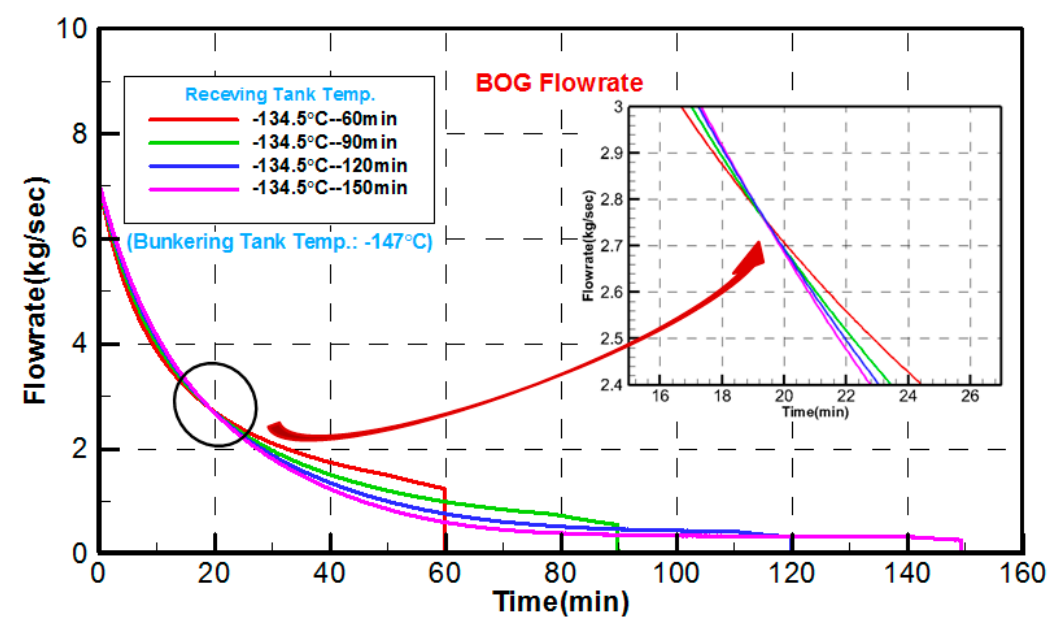

Figure 4. BOG flow rate variation based on different bunkering time limits.

\subsection{BOG Generation}

Heating is counteracted by the cooling effect of evaporation as the LNG boils off. The gas boiled to replace the reduction in the volume of the LNG or vapor in the tank while maintaining the LNG liquid and vapor in equilibrium at the cooler saturated temperature and pressure [7]. Therefore, no removal or slow removal of LNG and boil-off gas from the tank can increase the temperature and vapor pressure of the tank by the reason of heat flux into the tank, while rapid removal without forced generation of BOG could cause the LNG tank temperature to decrease. As a result, it is important to measure the temperature in the LNG fuel tanks when compared to the bunkered temperature of the LNG since temperature differences can significantly affect the vapor control procedure.

In the study, the receiving LNG was stored and transported under the LNG conditions as a cryogenic liquid. The capacity of the receiving ship was $700 \mathrm{~m}^{3}$. The LNG evaporated at temperatures above its boiling point while the boil-off-gas was generated in a manner similar to that for any other liquid. The BOG emerged from the heat ingress into the LNG during shipping, storage, and on/off loading operations [31].

Figure 5 shows the changes in the BOG generation for four different bunkering time limits. In the initial $35 \mathrm{~min}$, given the build-up of BOG flow rate, the BOG generation was proportional to the bunkering time limit. In order to optimally determine the relationship between the time limit and the BOG generation, the bunkering time limit was set as simulated for every alternate $10 \mathrm{~min}$ in a period ranging from $50 \mathrm{~min}$ to $150 \mathrm{~min}$ based on the BOG generation to determine the optimal bunkering time limit. As shown in Figure 6, in the period from $50 \mathrm{~min}$ to $120 \mathrm{~min}$, the amount of BOG generation change increased with increases in the bunkering time limit and peaked to $10,535.24 \mathrm{~kg}$ at $120 \mathrm{~min}$ and subsequently reduced gradually. Additionally, a decrease in the time limit decreases the amount 
of BOG generation. However, the bunkering time limit did not shorten without a limit given the restrictions such as the pump capacities and pipeline diameters. Thus, this suggests that the bunkering time should controlled within $120 \mathrm{~min}$ to avoid additional BOG generation when the capacity of the pump exceeds $100,000 \mathrm{~kg} / \mathrm{h}$. Conversely, the bunkering efficiency could be efficiently improved to reach the optimal time limit when the pump's capacity is lower than $100,000 \mathrm{~kg} / \mathrm{h}$.

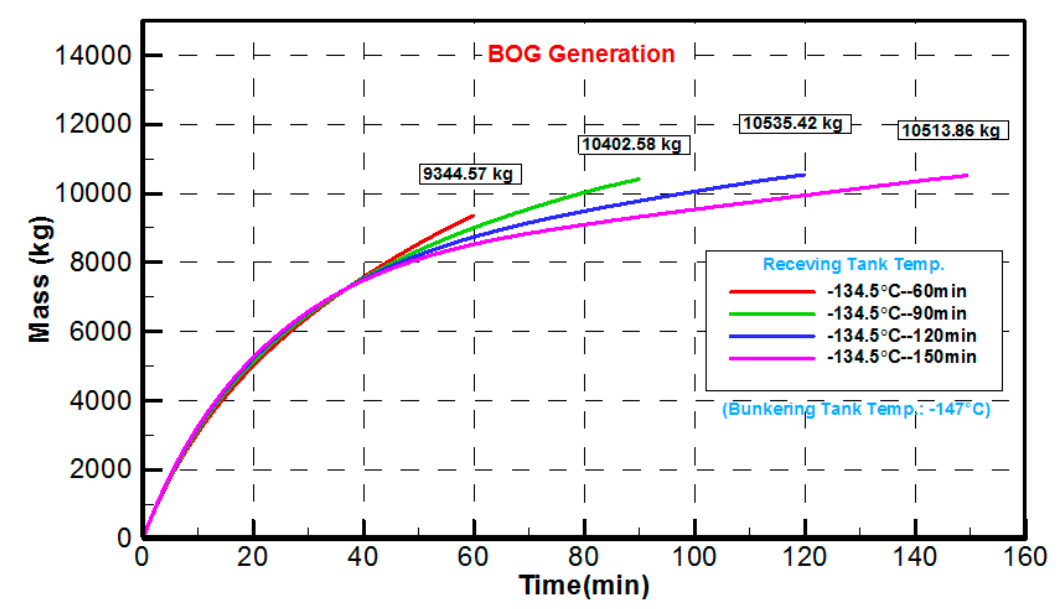

Figure 5. Effect of bunkering time on BOG generation at the receiving LNG storage tank.

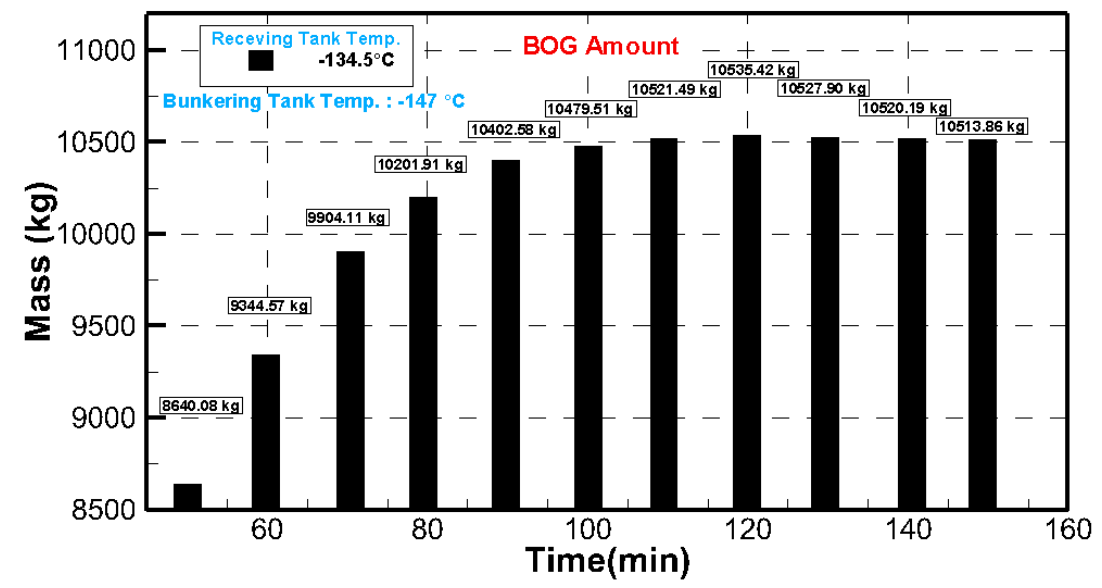

Figure 6. BOG profile during bunkering operation for the BOG from the receiving tank at different bunkering time limits (50-150 $\mathrm{min})$.

\subsection{Variations in the Bunker and Receiver Tank Pressure}

With respect to the safety system, if the tank temperature was allowed to increase in an unchecked manner, the pressure in the tank increased to the point where the pressure relief valves open. The temperature of the LNG at this point corresponded to the reference temperature. The reference temperature was the temperature corresponding to the saturated vapor pressure of the LNG at the set pressure of the pressure relief valves [7]. Evidently, the bunkering limit was always lower than the filling limit since the density of the LNG at the reference temperature was lower than the density at the bunkering temperature.

As shown in Figure 7, the variations in the bunker tank pressure are not obvious when compared with the receiving ship. This is due to the following reasons: On one side, given the tank pressure difference, the vapor was only unilaterally transferred into the bunker tank from the fuel tank of the receiving ship during the bunkering procedure. On the other side, the BOG generated from the bunker tank itself was limited, and the bunker tank was capacious. The variation in the tank pressure for the bunkering ship increased from 2.8 barg initially to $2.90-2.93$ barg at the end of each case, and the 
ending pressure was directly proportional to the bunkering time limit. Specifically, with respect to the level of the fuel tank for the receiving ship prior to $85 \%$, the tank pressure increased relatively quickly, and the variation was proportional to the bunkering time limit. This is because the mass and pressure of the outflowing LNG increased slowly while an increase in the bunkering time limit decreased the discharging LNG rate. Additionally, when the receiver tank reached $85 \%$, the pressure in the bunker tank increased due to decreases in LNG flow rate.

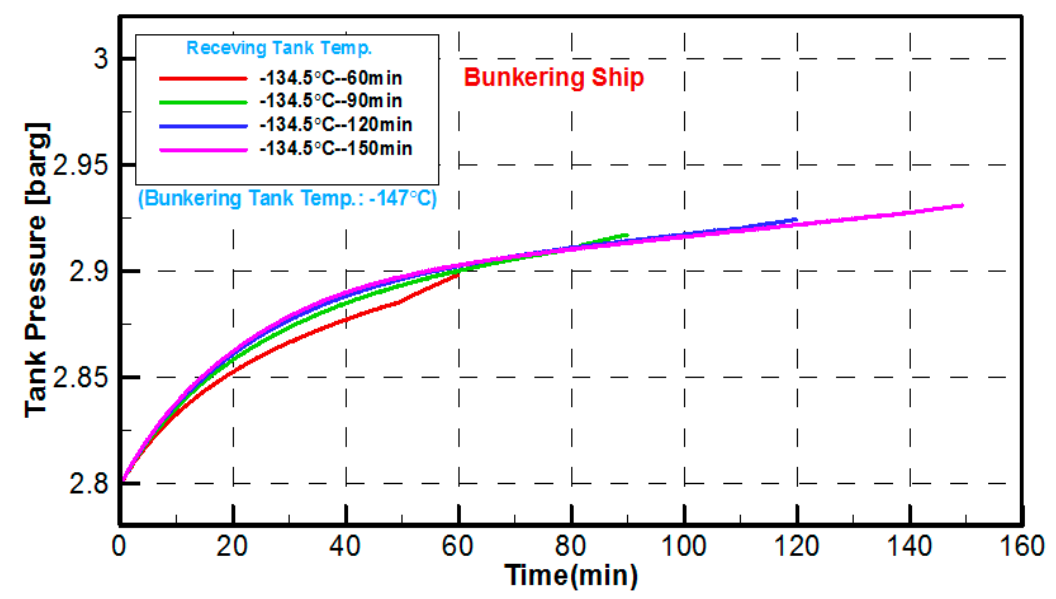

Figure 7. Pressure variation in the bunker cargo tank of the bunkering ship during the bunkering operation at different bunkering time limits.

As shown in Figure 8, the fuel tank pressure of the receiving ship is directly proportional to the time limit in the first $20 \mathrm{~min}$ in each case. The reasons are as follows: first, the LNG in bunker tank was transferred to the fuel tank of receiving ship with decreases in the temperature and pressure. Second, the aforementioned pressure in the fuel tank decreased quickly since the BOG pipelines were well connected with the bunker tank. Finally, the pressure reduction decreased if the fuel tank could obtain a higher LNG transfer flow rate during the bunkering procedure. Conversely, the tank pressure of the receiving ship was inversely proportional to the time limit after $20 \mathrm{~min}$. It was observed that the pressure variation in fuel tank for the receiving ship changed significantly, and the pressure reduced from 5.77 barg at the beginning to the 2.94-3.06 barg in the end of each case. The tank pressure difference between bunkering and receiving ship reduced and decreased with increases in the bunkering time limit.

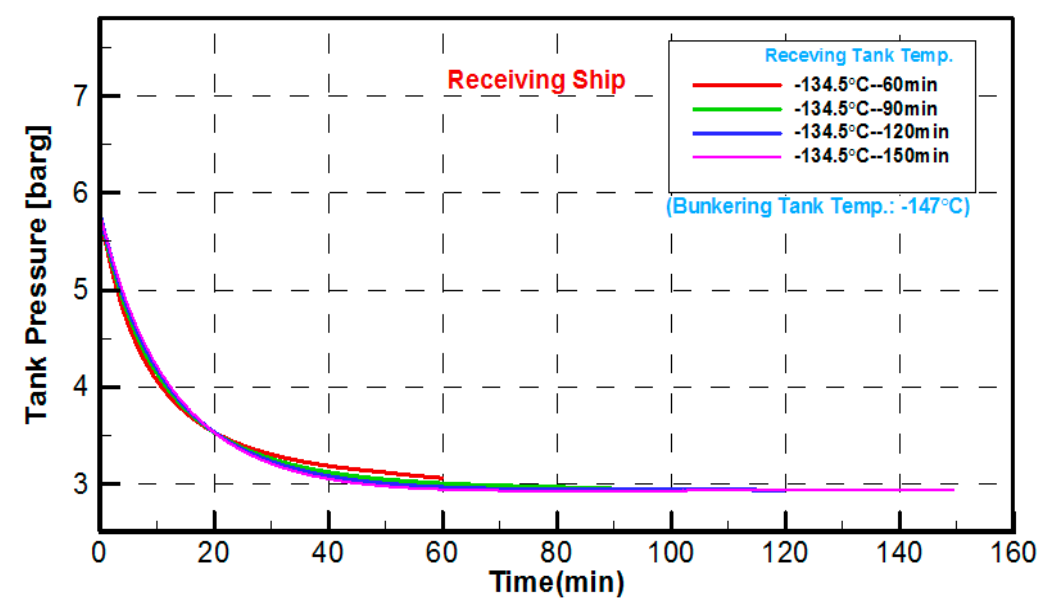

Figure 8. Pressure variation in the fuel tank of the receiving ship during the bunkering operation at different bunkering time limits. 


\subsection{LNG Flow Rate and Total LNG Bunkering Amount}

A few ships may require a shorter bunkering time when compared to others based on their operating profile. Based on the frequency of bunkering and the size of the fuel tanks, the owners may wish to maximize the bunkering rate [32].

As shown in Figure 9, the LNG flow rates in each case are different before the level of fuel tank reaches $85 \%$ in different bunkering cases (Take Table 2 as reference) while the flow rate reduces uniformly to $72,000 \mathrm{~kg} / \mathrm{h}$ when the level of fuel tank exceeds $85 \%$. When the level of fuel tank reached $90 \%$, the pump stopped working, the valve closed, and the entire bunkering procedure was completed. As shown in Figure 10, the total bunkering amount refers to the total mass of LNG that transferred from the bunkering ship to the receiving ship during the entire LNG bunkering procedure minus the total mass of BOG generation that passing through the BOG return pipeline. The total bunkering amount is not significantly related to the bunkering time limit. The gap between the maximum bunkering amount and the minimum bunkering amount was less than $0.5 \%$. In the case of 120 minutes, the maximum bunkering amount corresponds to 231.8 tons. Meanwhile, the trend of the total bunkering amount at different bunkering time limits was consistent with the change in the total amount of BOG. This is because the bunkering time limit with the higher BOG amount, the more LNG will be transferred from the bunkering ship, correspondingly.

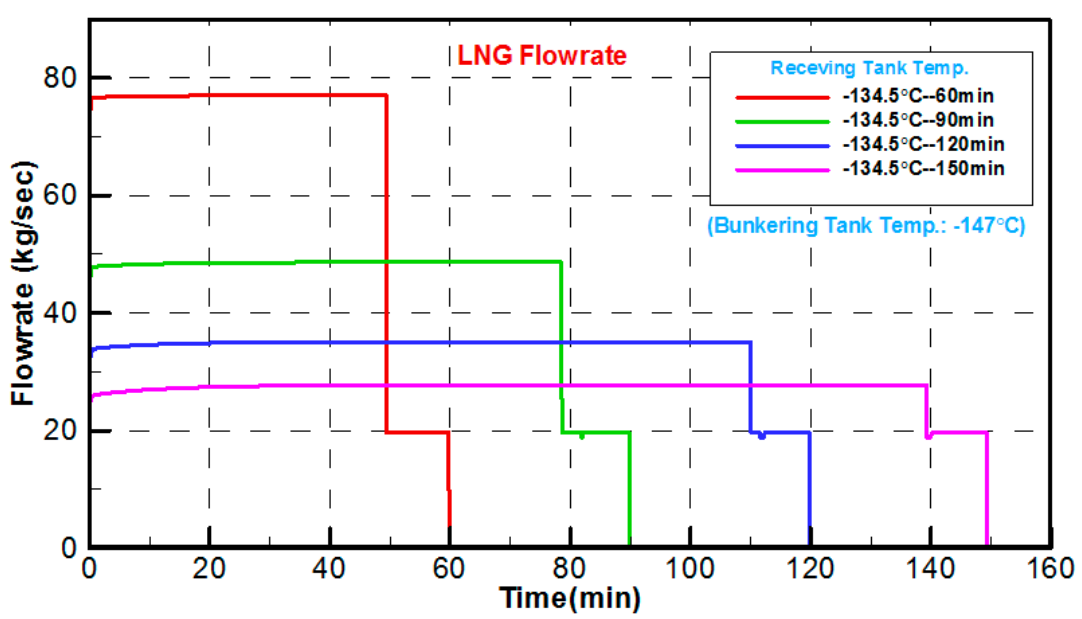

Figure 9. Relation between the LNG flow rate and the respective bunkering times.

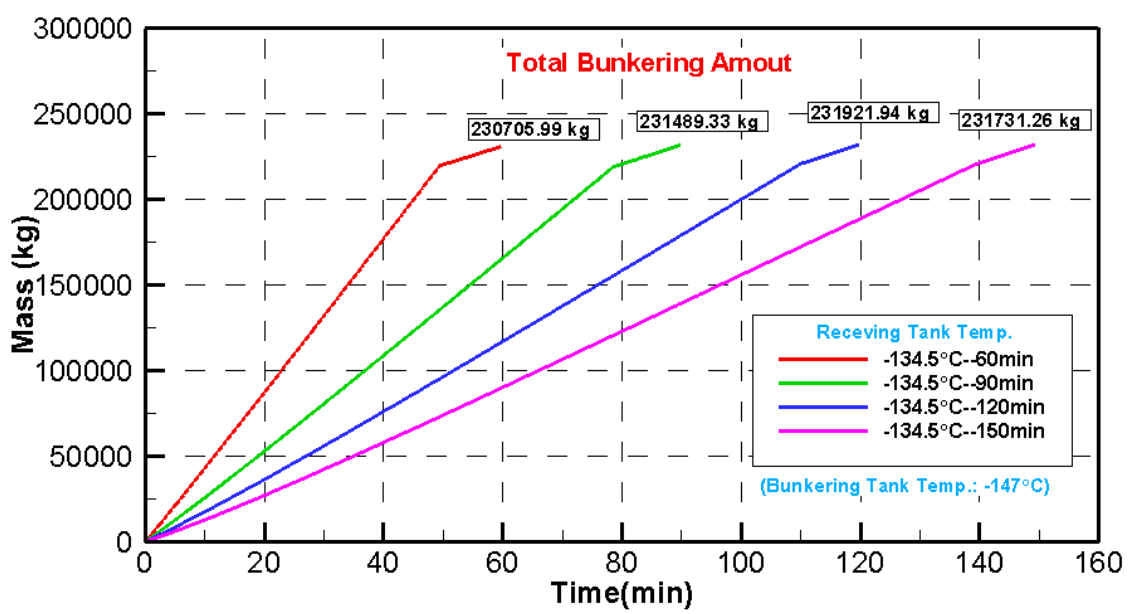

Figure 10. Total bunkering amounts with respect to different bunkering times and pump stops. 
As shown in Table 5, BOG is considered as a core consideration throughout the STS LNG bunkering procedure. The total amount of BOG generation by different bunkering time limits is not the same. Among them, the total amount of BOG is the highest in the $120 \mathrm{~min}$. case, whereas in the $60 \mathrm{~min}$ case is the least. When the bunkering time limit is less than 120 minutes, the BOG amount is proportional to the bunkering time limit. Therefore, the shorter the bunkering time limit is, the more benefits will generated in safety, efficiencies and others. Since the heat transfer can be carried out through the BOG return pipeline, the longer the time limit, the smaller the temperature difference between the two ships. Hence, with the increase of the bunkering time limit, the pressure difference between the bunkering ship and the receiving ship decreases. For the total bunkering amount, it is consistent with the trend of the total BOG amount.

Table 5. Quantity of state respect to different bunkering time limits (Finish Bunkering).

\begin{tabular}{|c|c|c|c|c|c|}
\hline Bunkering Time & Limit (min.) & 60 & 90 & 120 & 150 \\
\hline \multicolumn{2}{|c|}{ BOG Amount (kg) } & 9344.57 & 10402.58 & 10535.42 & 10513.86 \\
\hline \multirow{2}{*}{ Tank Pressure (Barg) } & Bunkering Ship & 2.90 & 2.93 & 2.93 & 2.93 \\
\hline & Receiving Ship & 3.06 & 2.99 & 2.97 & 2.94 \\
\hline \multicolumn{2}{|c|}{ Total Bunkering Amount (kg) } & 230705.99 & 231489.33 & 231921.94 & 231731.26 \\
\hline
\end{tabular}

\subsection{Calculation for Mass of BOG Amount}

As mentioned in Section 4.2, a dynamic simulation was carried out for the amount of BOG generated in the 50-150 min STS LNG bunkering process. However, through the dynamic simulation method, it is unrealistic to calculate the BOG amount generated in any bunkering time limit. Therefore, based on the simulated data, the Sigmoidal Weibull function type 2 (SWeibull 2) in OriginPro 2017 software (OriginLab Cor., Northampton, MA, USA) was used to fit the simulated data [33,34], as shown in Figure 11.

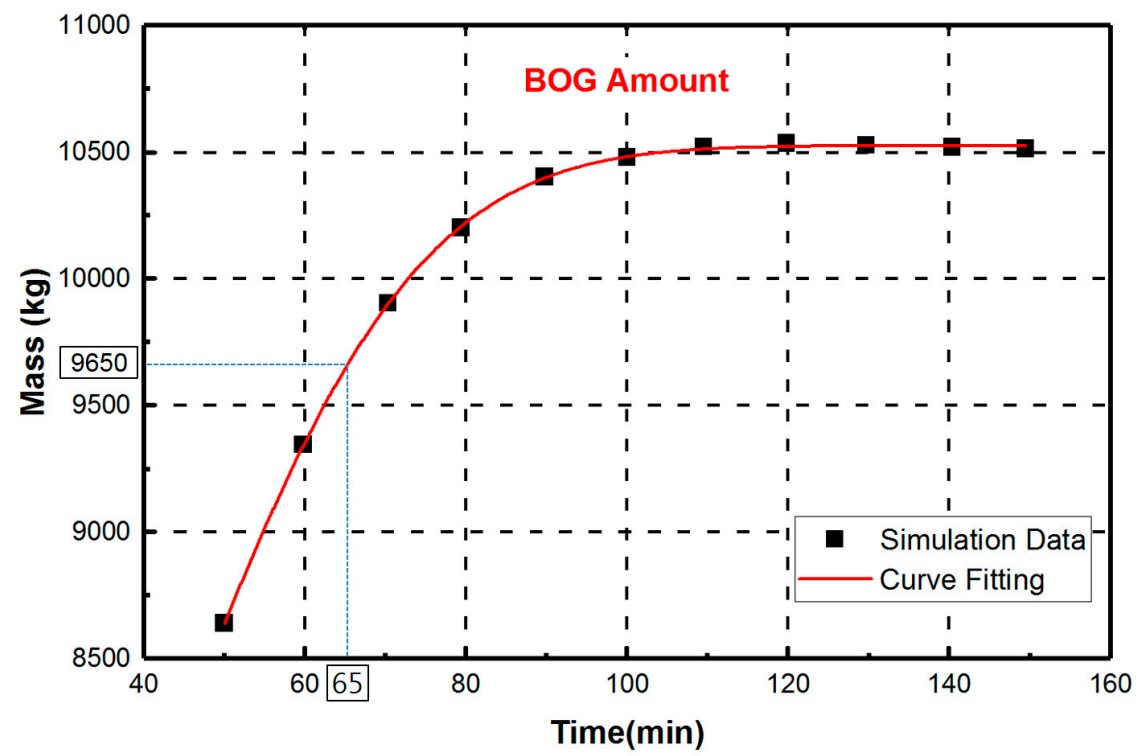

Figure 11. Mass of BOG generation amount and its curve fitting result.

According to the fitting curve, the mass of BOG generation amount could be performed simply by the following equation:

$$
\dot{m}_{B O G}=A-(A-B) e^{-(k t)^{d}}
$$


As shown in Figure 11, the fitting curve is quite consistent with the results of dynamic simulation. It has the advantage of suitable for development region. A correlation of the simulated data using the above formulation, and with the least squares estimates parameters $A, B, k$ and $d$ of $10,526.69,6,087.63$, 2.4313 and 0.0188 , respectively. The $\dot{m}_{B O G}$ presents the mass of BOG generation amount within the STS LNG bunkering time. For example, the value of BOG amount when the bunkering time at $65 \mathrm{~min}$ is approximately $9650 \mathrm{~kg}$.

\section{Conclusions}

The study focused on the changes in the BOG generation and other effects of ship-to-ship LNG bunkering procedures given differences in the bunkering time limit. Based on the dynamic simulation, an optimal ship-to-ship LNG bunkering time limit is proposed. In addition, a formula for calculating BOG amount which can substitute for simulation is established. The results for different bunkering time limits were obtained as follows:

(1) In the initial $20 \mathrm{~min}$ of all the bunkering cases, the BOG flow rate was directly proportional to the bunkering time limit. Conversely, the BOG flow rate was inversely proportional to the bunkering time limit after $20 \mathrm{~min}$.

(2) The bunkering time should be controlled within $120 \mathrm{~min}$ to avoid the generation of additional BOG when the capacity of the pump exceeded $100,000 \mathrm{~kg} / \mathrm{h}$. Conversely, when the pump's capacity was lower than $100,000 \mathrm{~kg} / \mathrm{h}$, the bunkering efficiency could be improved properly to reach the optimal time limit.

(3) The tank pressure difference between bunkering and receiving ship reduced and decreased with increases in the bunkering time limit. Additionally, when the level of fuel tank for the receiving ship reached $85 \%$, the pressure in the bunker tank increased due to decreases in the LNG flow rate.

Several challenges were identified for the future studies. The present study only provides a mathematical model for the calculation of the total amount of BOG generation by the STS LNG bunkering method, while the current LNG bunkering methods also include the Truck-to-ship (TTS) and Pipe-to-ship (PTS). In order to develop the general BOG equation, a number of LNG bunkering scenarios in different conditions need to be examined. What's more, the further research should attach importance to the impacts of the environmental conditions in the surrounding bunkering area to the BOG generation. The factors such as sea stability, atmospheric temperature and other conditions will be included to enhance the reliability of data.

Additionally, the limitation of present study was that the object fuel tank for the receiving ship is the IMO type C pressure tank which commonly used in the current LNG fueled ships. The bunkering conditions for large container ships with the possibility of using the membrane tanks in the future were not considered. Although this study had some limitation, considering that the lack of industry practices and standards in determining the LNG bunkering time limit and the mass of BOG generation calculations, it is believed that the insights present in this paper could provide useful information as a complement.

Author Contributions: H.K. was the supervisor of this research team, he conceived the original idea and provided technical expertise to improve the quality of this paper; Y.S. carried out the simulation and analyzed the data; Y.L. supported work. All co-authors discussed the data and contributed to the final manuscript.

Acknowledgments: This work was part of "Test evaluation for LNG bunkering equipment and development of test technology (Grant No. 20180048)" supported by the Ministry of Oceans and Fisheries of Korea government.

Conflicts of Interest: The authors declare no conflict of interest. 


\section{Nomenclature}

$\begin{array}{ll}\text { BOG } & \text { Boil-off Gas } \\ \text { BL } & \text { Bunkering Limit } \\ \text { CFD } & \text { Computational Fluid Dynamics } \\ \text { CH }_{4} & \text { Methane } \\ \text { ECAs } & \text { Emission Control Areas } \\ \text { ESD } & \text { Emergency Shutdown } \\ \text { ERC } & \text { Emergency Release Coupling } \\ \text { FL } & \text { Filling Limit } \\ \text { JBOG } & \text { Jetty Boil-off Gas } \\ \text { HFO } & \text { Heavy Fuel Oil } \\ \text { IMO } & \text { International Maritime Organization } \\ \text { IQRA } & \text { Integrated Quantitative Risk Assessment } \\ \text { LNG } & \text { Liquefied Natural Gas } \\ \text { LNG-FPSO } & \text { Floating Production Storage and Offloading unit for Liquefied Natural Gas } \\ \text { MGO } & \text { Marine Gas Oil } \\ \text { PBMR } & \text { Pebble Bed Modular Reactor Company } \\ \text { PFD } & \text { Process Flow Diagram } \\ \text { PTS } & \text { Pipeline-to-Ship } \\ \text { SO } & \text { Sulphur Oxide } \\ \text { SRK } & \text { Soave-Redlich-Kwong equation } \\ \text { STS } & \text { Ship-to-Ship } \\ \text { SWeibull 2 } & \text { Sigmoidal Weibull function type 2 } \\ \text { TTS } & \text { Truck-to-Ship } \\ & \end{array}$

\section{Symbols}

$\begin{array}{ll}a & \text { Energy parameter } \\ \alpha & \text { Alpha function } \\ b & \text { Size parameter } \\ D & \text { Diameter of pipeline } \\ \Delta \mathrm{p} & \text { Pressure difference } \\ \Delta \mathrm{t} & \text { Temperature difference } \\ \mathrm{k} & \text { Function of } \omega \\ \dot{m} & \text { Mass flow rate } \\ \dot{m}_{B O G} & \text { Mass of BOG } \\ P & \text { Pressure } \\ P_{C} & \text { Pressure at critical point } \\ \rho_{B} & \text { LNG density at bunkering temperature } \\ \rho_{R} & \text { LNG density at reference temperature } \\ Q & \text { Volume flow rate } \\ R & \text { Gas Constant } \\ T & \text { Temperature } \\ T_{C} & \text { Temperature at critical point } \\ t & \text { Time } \\ V & \text { Velocity } \\ V_{m} & \text { Molar volume } \\ \omega & \text { Acentric factor }\end{array}$

\section{References}

1. Wang, S.Y.; Notteboom, T. The Adoption of Liquefied Natural Gas as a Ship Fuel: A Systematic Review of Perspectives and Challenges. Transp. Rev. 2014, 34, 749-774. [CrossRef] 
2. Adachi, M.; Kosaka, H.; Fukuda, T.; Ohashi, S.; Harumi, K. Economic analysis of trans-ocean LNG-fueled container ship. J. Mar. Sci. Technol. 2014, 19, 470-478. [CrossRef]

3. Notteboom, T. The impact of low sulphur fuel requirements in shipping on the competitiveness of roro shipping in Northern Europe. WMU J. Marit. Aff. 2011, 10, 63-95. [CrossRef]

4. Xu, J.Y.; Fan, H.J.; Wu, S.P.; Shi, G.Z. Research on LNG Ship to Ship (STS) Bunkering Operations. J. Ship Eng. 2015, 1, 7-10.

5. Lee, M.H.; Shao, Y.D.; Kim, Y.T.; Kang, H.K. Performance characteristics under various load conditions of coastal ship with LNG-powered system. J. Korean Soc. Mar. Eng. 2017, 5, 424-430. [CrossRef]

6. IMO. Sulphur Oxides $\left(\mathrm{SO}_{\mathrm{x}}\right)$ and Particulate Matter $(\mathrm{PM})$-Regulation 14 . Available online: http:/ / www.imo.org/en/OurWork/Environment/PollutionPrevention/AirPollution/Pages/Sulphuroxides-(SOx)-\%E2\%80\%93-Regulation-14.aspx (accessed on 20 April 2018).

7. ABS. LNG bunkering: Technical and Operational Advisory; ABS: Houston, TX, USA, 2014.

8. Ryu, J.H. Concept for Protection against Overpressure Caused by BOG Generated during Ship-to-Ship LNG Bunkering. Master's Thesis, Korea Advanced Institute of Science and Technology (KAIST), Daejeon, Korea, 2012.

9. Shao, Y.D.; Kang, H.K.; Yoon, S.D.; Kim, Y.T. Dynamic Simulation for Boil-off Gas in LNG Fueled Ship during Ship-to-ship Bunkering Process. In Proceedings of the International Symposium on Marine Engineering (ISME), Tokyo, Japan, 15-19 October 2017; Japan Institute of Marine Engineering (JIME): Tokyo, Japan, 2017.

10. Yun, S.; Ryu, J.; Seo, S.; Lee, S.; Chung, H.; Seo, Y.; Chang, D. Conceptual design of an offshore LNG bunkering terminal: A case study of Busan Port. J. Mar. Sci. Technol. 2015, 2, 226-237. [CrossRef]

11. Zakaria, M.; Osman, K.; Yusof, A.; Hanafi, H.; Saadun, M.; Manaf, M. Parametric analysis on boil-off gas rate inside liquefied natural gas storage tank. J. Mech. Eng. Sci. 2014, 6, 845-853. [CrossRef]

12. Bahgat, W.M. Proposed method for dealing with boil-off gas on board LNG carriers during loaded passage. Int. J. Multidiscip. Curr. Res. 2015, 3, 508-512. [CrossRef]

13. Fan, H.; Cheng, K.; Wu, S. CFD based simulation of LNG release during bunkering and cargo loading/unloading simultaneous operations of a containership. J. Ship. Ocean Eng. 2017, 7, 51-58.

14. Sun, B.; Guo, K.; Pareek, V.K. Hazardous consequence dynamic simulation of LNG spill on water for ship-to-ship bunkering. Process Saf. Environ. Prot. 2017, 107, 402-413. [CrossRef]

15. Jeong, B.; Lee, B.S.; Zhou, P.; Ha, S. Evaluation of safety exclusion zone for LNG bunkering station on LNG-fuelled ships. J. Mar. Eng. Technol. 2017, 4177, 1-24. [CrossRef]

16. Kurle, Y.M.; Wang, S.; Xu, Q. Simulation study on boil-off gas minimization and recovery strategies at LNG exporting terminals. Appl. Energy 2015, 156, 628-641. [CrossRef]

17. Kurle, Y.M.; Wang, S.; Xu, Q. Dynamic simulation of LNG loading, BOG generation, and BOG recovery at LNG exporting terminals. Comput. Chem. Eng. 2017, 97, 47-58. [CrossRef]

18. Hasan, M.M.F.; Zheng, A.M.; Karimi, I.A. Minimizing boil-off losses in liquefied natural gas transportation. Ind. Eng. Chem. Res. 2009, 48, 9571-9580. [CrossRef]

19. Yan, G.; Gu, Y. Effect of parameters on performance of LNG-FPSO offloading system in offshore associated gas fields. Appl. Energy 2010, 87, 3393-3400. [CrossRef]

20. International Maritime Organization. International Code for the Construction and Equipment of Ships Carrying Liquefied Gas in Bulk; IMO: London, UK, 2003.

21. Aspen Technology. Aspen. HYSYS Operations Guide; V10; Aspen Technology Inc.: Burlington, MA, USA, 2017.

22. ISO 20519:2017. Ships and Marine Technology_Specification for Bunkering of Liquefied Natural Gas Fueled Vessels, 1st ed.; ISO: Geneva, Switzerland, 2017.

23. Li, Y.J.; Chen, X.S. Dynamic Simulation for Improving the Performance of Boil-Off Gas Recondensation System at LNG Receiving Terminals. Chem. Eng. Comm. 2012, 10, 1251-1262. [CrossRef]

24. Soave, G. Equilibrium constants from a modified Redlich-Kwong equation of state. Chem. Eng. Sci. 1972, 6, 1197-1203. [CrossRef]

25. Stryjek, R.; Vera, J.H. PRSV: An Improved Peng- Robinson Equation of State for Pure Compounds and Mixtures. Can. J. Chem. Eng. 1986, 64, 323-333. [CrossRef]

26. Lee, S.; Jeon, J.; Lee, U.; Lee, C. A Novel Dynamic Modeling Methodology for Boil-Off Gas Recondensers in Liquefied Natural Gas Terminals. J. Chem. Eng. Jpn 2015, 48, 841-847. [CrossRef] 
27. Effendy, S.; Khan, M.S.; Farooq, S.; Karimi, I.A. Dynamic modelling and optimization of an LNG storage tank in a regasification terminal with semi-analytical solutions for N 2-free LNG. Comput. Chem. Eng. 2017, 99, 40-50. [CrossRef]

28. Shariq, M.; Effendy, S.; Karimi, I.A.; Wazwaz, A. Improving design and operation at LNG regasification terminals through a corrected storage tank model. Appl. Therm. Eng. 2019, 149, 344-353.

29. Park, C.; Cho, B.; Lee, S.; Kwon, Y. Study on the Re-liquefaction Processing for Boil off Gas System of Floating Offshore LNG Bunkering Terminal. In Proceedings of the Twenty-sixth International Ocean and Polar Engineering Conference, Roodes, Greece, 26 June-1 July 2016; International Society of Offshore and Polar Engineers (ISOPE): Mountain View, CA, USA, 2016.

30. Ravenswaay, J.P.; Greyvenstein, G.P.; Neikerk, W.M.K.; Labuschagne, J.T. Verification and validation of the HTGR systems CFD code Flownex. Nucl. Eng. Des. 2006, 5-6, 491-501. [CrossRef]

31. Dobrata, L.B.; Komar, I. Problem of Boil-off in LNG Supply Chain. J. Trans. Marit. Sci. 2013, 2, 91-100. [CrossRef]

32. Shao, Y.D.; Lee, Y.H.; Kim, Y.T.; Kang, H.K. Parametric Investigation of BOG Generation for Ship-to-Ship LNG Bunkering. J. Korean Soc. Mar. Environ. Saf. 2018, 3, 352-359. [CrossRef]

33. Seo, Y.; Lee, S.; Kim, J.; Huh, C.; Chang, D. Determination of optimal volume of temporary storage tanks in a ship-based carbon capture and storage (CCS) chain using life cycle cost (LCC) including unavailability cost. Int. J. Greenh. Gas Control 2017, 64, 11-22. [CrossRef]

34. Nguyen, L.; Kim, M.; Choi, B. An experimental investigation of the evaporation of cryogenic-liquid- pool spreading on concrete ground. Appl. Therm. Eng. 2017, 123, 196-204. [CrossRef]

(C) 2019 by the authors. Licensee MDPI, Basel, Switzerland. This article is an open access article distributed under the terms and conditions of the Creative Commons Attribution (CC BY) license (http:/ / creativecommons.org/licenses/by/4.0/). 